\title{
Simple method for simultaneous quantification of two new derivatives of betulinic and ursolic acids with antimalarial activity by RP-HPLC-UV-CAD
}

\author{
Leonardo Trevisan Secretti*a, Andrea Pereira ${ }^{\mathrm{a}}$, Simone Cristina Baggio Gnoatto ${ }^{\mathrm{a}}$, Lívia Maronesi Bueno ${ }^{\mathrm{a}}$, Pâmela C \\ Lukasewicz Ferreira ${ }^{\mathrm{a},}$ Pedro Eduardo Froehlich ${ }^{\mathrm{a}}$.
${ }^{a}$ Programa de Pós-Graduação em Ciências Farmacêuticas, Faculdade de Farmácia, Universidade Federal do Rio Grande do Sul (UFRGS), Porto Alegre, RS, Brazil.

\author{
*Corresponding author: leonardotsec@gmail.com
}

\begin{abstract}
Endemic in more than 90 countries and territories, malaria is the most widely, populational, and geographically, parasitic disease in the world. Plasmodium sp. resistance to available drugs is one of the biggest problems for malaria eradication. In this study, we develop a method for the simultaneous determination of two new derivatives of betulinic and ursolic acids with antimalarial activity designated 3-O-butanoylbetulinic and 3-O-butanoylursolic acids. An analytical method was developed by high-performance liquid chromatography coupled, in series, to ultraviolet (UV) and charged aerosol (CAD) detectors. The chromatographic system, operated isocratically by reversed-phase, consisted in a mobile phase composed of acetonitrile: water $\mathrm{pH} 3.0$ adjusted with formic acid $(85: 15, \mathrm{v} / \mathrm{v})$, flow rate of $1.2 \mathrm{~mL} / \mathrm{min}$ and a PhenoSphere Next octadecylsilane column ( $250 \mathrm{~mm} \times 4.6 \mathrm{~mm}, 5 \mu \mathrm{m}$ particle size $)$. Chromatograms were recorded simultaneously in UV and $\mathrm{CAD}$, at a concentration of $50 \mu \mathrm{g} \mathrm{mL}-1$, an injection volume of $20 \mu \mathrm{L}$ at a controlled temperature of $50{ }^{\circ} \mathrm{C}$. The method was found to be selective, linear $(r>0.99)$, precise (RSD $<2.0 \%)$, accurate, and robust for both analytes, and considered statistically validated, and can be applied to the identification and quantification of these new drug candidates.
\end{abstract}

Keywords: Malaria, HPLC method, charged aerosol detector, drug candidates, mass balance.

https://doi.org/10.22456/2527-2616.108249

\section{Introduction}

Malaria is considered one of the greatest challenges of the 21 st century. In 2018, an estimated 228 million cases of malaria occurred worldwide, reported by 91 countries and territories, compared with 231 million cases in 2017. In the same year, an estimated US\$ 2.7 billion was invested around the world in malaria control and elimination by governments of malaria endemic countries [1].

The pathology, caused by several protozoa of the genus Plasmodium sp., has vectoral transmission by mosquitoes Anopheles sp., which contribute to the broad geographic distribution and the difficulty of controlling the disease [2]. Furthermore, the resistance of the plasmodium to the current drugs is a major problem in the eradication of malaria. In the 1950s, resistance to chloroquine, the most widely used drug, was detected in South Asia and South America for the first time. In 10 years, the problem was observed in the African continent [3]. Recently, there was a rapid worldwide increase in the resistance of $P$. falciparum, the most virulent species, to the drug [4] with children from 1 to 5 years having the highest incidence and mortality [1].

Betulinic acid (BA) is a naturally occurring pentacyclic lupane-like triterpene distributed in the Kingdom Plantae [5]. Several biological activities for BA and its derivatives have been discovered and studied. These include antimalarial [6,7], anti-HIV [8-10], antineoplastic [11], antibacterial [12,13] and antileishmanicidal [14], among others. Ursolic acid (UA) is a triterpenic secondary metabolite with several known activities, such as antimalarial [15], anticancer [16], anti-inflammatory [17] and antioxidant [18]. In this context, Silva et al. developed a semi-synthesis method to a series of betulinic and ursolic acid analogues aiming to improve the therapeutic activity and reduce toxicity of such molecules. The study investigates carbon-3 esterification, resulting in two noncytotoxic, short side acyl chain compounds (Fig. 1), designated 3-O-butanoylbetulinic acid (3-OBB) and 3-Obutanoylursolic acid (3-OBU), presenting anti-malarial activity against chloroquine-sensitive $P$. falciparum 3D7 up to five times higher $\left(\mathrm{IC}_{50}\right.$ of $5 \pm 0,14 \mu \mathrm{m}$ and $7 \pm 0,15$ $\mu \mathrm{m}$, respectively) than its precursors, BA and UA [7].
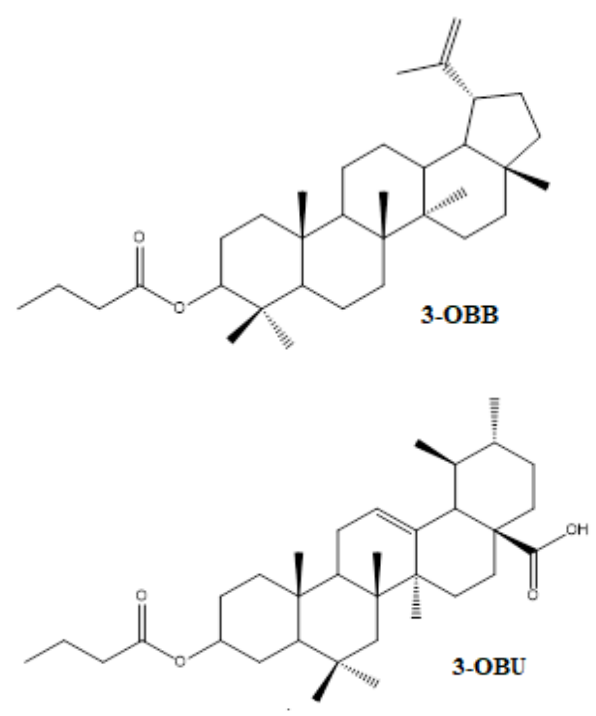

Figure 1. Chemical structures of 3-O-butanoylbetulinic acid and 3-O-butanoylursolic acid. 
Quality control of anti-malarial drugs is very important to assure treatment efficacy and to avoid the development of resistance [19]. However, there are no reported methods regarding the identification and quantitation of 3-OBB and 3-OBU. Hence, in this study, a simple and sensitive reversed-phase high-performance liquid chromatography method coupled, in line, to ultraviolet and charged aerosol detectors (RP-HPLC-UV-CAD) for the simultaneous determination of these molecules was developed and validated. Beyond the usual UV detection, charged aerosol detection was chosen because it is considered a universal detector for nonvolatile analytes and has a response independent of chemical properties [20], characteristics that work in favor of low ultraviolet absorptive molecules like 3-OBB and 3-OBU and their impurities. In addition, CAD was used to identify nonchromophore organic impurities in mass balance. The developed method can be applied in further studies with these drug candidates and quality control issues, such as the preparation of chemical reference material that will improve the quality of the data obtained in those studies.

\section{Materials and Methods}

\section{Instrumentation}

The analytical method was developed and validated in a Shimadzu LC system (Kyoto, Japan) equipped with a LC20AT gradient pump, DGU-14A vacuum degasser and CTO-10A column oven coupled in series with SPDM10A Diode Array Detector and Corona CAD (ESA Bioscience, Chelmsford, MA, USA). CAD detection was carried out using nitrogen as nebulizer gas (35 psi). Chromeleon 6.8 software (Dionex Corporation, Sunnyvale, CA, USA) and LC Solutions (Shimadzu, Kyoto, Japan) were used for the instrument control, data acquisition and analysis of the CAD and UV results, respectively.

\section{Chemicals and Materials}

BA and UA were provided by the Laboratory of Phytochemistry and Organic Synthesis - Federal University of Rio Grande do Sul, Brazil. BA and UA were obtained from Platanus acerifolia bark (2.0\% yield) and industrial residue of apple peel Malus domestica $(2.8 \%$ yield), respectively.

Butyric anhydride, dimethylaminopyridine, pyridine and cyclohexane $(\geq 99.0 \%, \geq 99.0 \%, \geq 99.0 \%$ and $99.5 \%)$ used in the semisynthesis of 3-OBB and 3-OBU acids were obtained from Sigma-Aldrich (Germany). Dichloromethane $(99.5 \%)$ were purchased from VETEC (Rio de Janeiro, Brazil). Silica gel 60 and silica gel 60 F254 TLC plates used during the purification of the compounds were purchased from Merck (Germany). Acetonitrile (HPLC grade) and formic acid (98\%) were purchased from Merck (Germany). Purified water was produced by a Milli-Q system (Millipore Corp., MA, USA).

\section{Semi-synthesis of 3-OBB and 3-OBU}

Semi-synthesis was performed as described by Silva et al [7]. Butyric anhydride (1.1 mmol, 5 Eq), 4dimethylaminopyridine $(0.22 \mathrm{mmol}, 1 \mathrm{Eq})$ and the acid of interest (betulinic or ursolic) diluted in pyridine $(0.22$ mmol, 1Eq) were added in a round bottom flask and refluxed for $1 \mathrm{~h}$ in a nitrogen atmosphere at room temperature. Purification of 3-OBB and 3-OBU were carried out using column chromatography. Silica gel 60 was used as stationary phase and different proportions of dichloromethane and cyclohexane were used as mobile phase. Analytical thin layer chromatography was performed to identify the synthesized compounds [7]. Further purification was performed by recrystallization using $60^{\circ} \mathrm{C}$ acetonitrile.

Melting range (FP 90, Mettler Toledo, Switzerland), differential scanning calorimetry (DSC-60, Shimadzu, Japan), infrared spectroscopy (Spectrum BX, Perkin Elmer, USA) and nuclear magnetic resonance spectroscopy (NMR ${ }^{1} \mathrm{H}$ and ${ }^{13} \mathrm{C}$ ) (DPX, Bruker, Germany) were used to identify and characterize the synthesized compounds (shown in supplementary data).

\section{Mass balance}

For the application of analytical methods, chemical reference standards are commonly used, comparatively, to identity and quantify drug content. In this case, as we synthesized these molecules and there is no compendial standard available, we decided to perform a mass balance to evaluate the purity of the compounds. Mass balance consider inorganic (residue on ignition), organic (HPLCUV-CAD) and volatile (loss on drying) impurities (100 impurities\%) $(\mathrm{n}=3)$ [21]. Besides quantifying the compounds' purity, mass balance offers the ability to detect shifts in the synthesis and purification processes.

\section{Chromatographic conditions}

LC-UV-CAD system was developed using a PhenoSphere Next C18 (250 x $4.6 \mathrm{~mm}$, particle size $5 \mu \mathrm{m}$, Phenomenex) column at $50{ }^{\circ} \mathrm{C}$. An isocratic elution was achieved by using a mobile phase consisted of acetonitrile:water with $\mathrm{pH}$ adjusted to 3.0 with formic acid $(85: 15, \mathrm{v} / \mathrm{v})$. The flow rate was set at $1.2 \mathrm{~mL} / \mathrm{min}$ and injection volume was $20 \mu \mathrm{L}$. For UV detection, a wavelength of $210 \mathrm{~nm}$ was used. For CAD detection, nitrogen pressure was set at 35 psi. 3-OBU and 3-OBB were retained in the system for 24 and 27 minutes, respectively.

\section{Standard stock and working solutions}

Stock solutions of 3-OBB and 3-OBU were individually prepared by transferring $25.0 \mathrm{mg}$ of each purified substance to a $100 \mathrm{~mL}$ volumetric flask. Substances were dissolved in $10 \mathrm{~mL}$ of dichloromethane and the volumes were completed with mobile phase to the final concentration of $250.0 \mu \mathrm{g} / \mathrm{mL}$. The required working 
solutions were prepared by further dilutions in mobile phase.

\section{Validation of the analytical method}

Method validation was performed according to current guidelines [22, 23].

\section{Selectivity}

Selectivity of the method was performed using qualitative individual solutions containing diluent, BA, UA, 3-OBB acid and 3-OBU. A solution containing all compounds, simultaneously, to identify the elution times and to prove the selectivity of the analytical method was also evaluated. BA and UA were chosen, as synthetic precursors, to ensure the method discrimination once they have similar chemical structure to the synthesized 3-OBB and 3-OBU and, therefore, this evaluation was considered critical to validate specificity. Peak purity was verified by UV-DAD detection.

\section{Linearity, $L O D$ and $L O Q$}

The linearity of the method was verified by the construction of three independent calibration curves prepared at five concentration levels: 25.0, 37.5, 50.0, 62.5 and $75.0 \mu \mathrm{g} / \mathrm{mL}(50 \%-150 \%$ of the nominal concentration). Triplicate determinations at each concentration level were performed and concentration versus area values were plotted. Results were statically evaluated by linear regression of the mean curve $(\alpha=$ $0.05)$, correlation coefficient (r), residue distribution and homoscedasticity. Limit of detection (LOD) and Limit of quantification (LOQ) were determined on the signal-tonoise ratio of 3:1 and 10:1, respectively.

\section{Precision and accuracy}

Precision was determined by six replicates of each sample, prepared individually, at the concentration of 50.0 $\mu \mathrm{g} / \mathrm{mL}$, in two different days (day 1 as repeatability and day 2 to accomplish intermediate precision). As there is not a compendial standard available, the ratio between the practical concentration of the samples and the arearesponse was used as response factor (RF). The relative standard deviation (RSD) of the RF values were evaluated. Accuracy was inferred after the establishment of linearity, selectivity and precision [22].

\section{Solution stability}

Solutions of 3-OBU and 3-OBB at working concentrations of $50 \mu \mathrm{g} / \mathrm{mL}$ were tested for 24,48 and 72 $\mathrm{h}$ at $25^{\circ} \mathrm{C}$. The results were compared with those obtained with the freshly prepared solution.

\section{Results and discussion}

\section{HPLC method development}

The proposed RP-LC method was optimized with the aim to develop a simple, rapid and suitable analytical method for separation, identification and quantitation of two new 3-O-butanoyl derivatives of betulinic and ursolic acids with anti-malaric activity. Although CAD detection is not as common as UV-DAD, it was a valuable tool in mass balance investigation and might be as valuable in further studies with these two analytes, considering their low molar absorptivity. The developed LC-UV-CAD method demonstrated good selectivity and sensitivity to identify and quantify 3-OBB and 3-OBU in the presence of related molecules (BA and UA).

The final chromatographic conditions established by the authors were selected after the robustness study, evaluating changes such as different batch column, flow rate $(1.1 \mathrm{~mL} / \mathrm{min}$ and $1.3 \mathrm{~mL} / \mathrm{min}), \mathrm{pH}$ of the aqueous phase (2.9 and 3.1) and mobile phase composition (83:17, $\mathrm{v} / \mathrm{v})$ and $(87: 13, \mathrm{v} / \mathrm{v})$. Conditions were chosen based on peak performances (such as theoretical plates, capacity factor, tailing factor) and the best resolution between analytes.

Different chromatographic systems were tested using different columns polarities and sizes. Separation between these similar structured acids, with adequate resolution, was possible with the use of a $\mathrm{C}_{18} 250 \times 4.6 \mathrm{~mm}, 5.0 \mu \mathrm{m}$ column. The wavelength was defined by the evaluation of the absorptivity profile of the molecules.

\section{Mass Balance}

Recommended by the world health organization (WHO) and official compendia [24], mass balance demonstrated to be an accurate and reproducible methodology to assess the compound purities [25].

After purification, final purities of $94.56 \%$ and $83.38 \%$ were achieved, for 3-OBB and 3-OBU, respectively. Organic impurities were evaluated in UV and CAD, and the impurities with biggest areas (\%) were considered to the mass balance. Chromatographic profile was different in both detectors, with an increased number of impurities detected by $\mathrm{CAD}$, inferring the absence of chromophores in those impurities. Compound 3-OBU acid presented high profile of organic impurities, however, the purity of $83.38 \%$ did not interfere with the identification and characterization of the compound, but further purification should be done to establish a reference standard. Results are shown in table 1. 
Table 1. Purity results of 3-OBB and 3-OBU acids achieved by mass balance.

\begin{tabular}{cccccc}
\hline Compound & $\begin{array}{c}\text { Inorganic } \\
\text { Impurities }^{\mathbf{a}}\end{array}$ & $\begin{array}{c}\text { Organic } \\
\text { Impurities }^{\mathbf{b}}\end{array}$ & $\begin{array}{c}\text { Volatile } \\
\text { impurities }^{\mathbf{c}}\end{array}$ & Total impurities & Total purity \\
\hline 3-OBB & $0.01 \pm 0.0002 \%$ & $5.10 \pm 0.18 \%$ & $0.32 \pm 0.04 \%$ & $5.43 \pm 0.2202 \%$ & $94.57 \pm 0.2202 \%$ \\
\hline 3 -OBU & $0.08 \pm 0.0009 \%$ & $15.78 \pm 1.21 \%$ & $0.75 \pm 0.06 \%$ & $16.62 \pm 1.9609 \%$ & $83.38 \pm 1.9609 \%$ \\
\hline
\end{tabular}

${ }^{a}$ Residue on ignition (USP 43); ${ }^{\mathrm{b}}$ HPLC-UV-CAD (same validated method was applied); ${ }^{\mathrm{c}}$ Loss on drying (USP 43). Data shown represent the mean of $n=3$ independent samples.

\section{Method Validation}

\section{Selectivity}

Selectivity of the method was demonstrated by adequate resolution among BA, UA, 3-OBB and 3-OBU (3.1 between the synthesized compounds). Also, matrix components, impurities and the chromatographic system (e.g. diluent) did not interfere with 3-OBB and 3-OBU peaks (Fig. 2). Peak purity by UV-DAD detection was higher than 0.99 for both peaks.

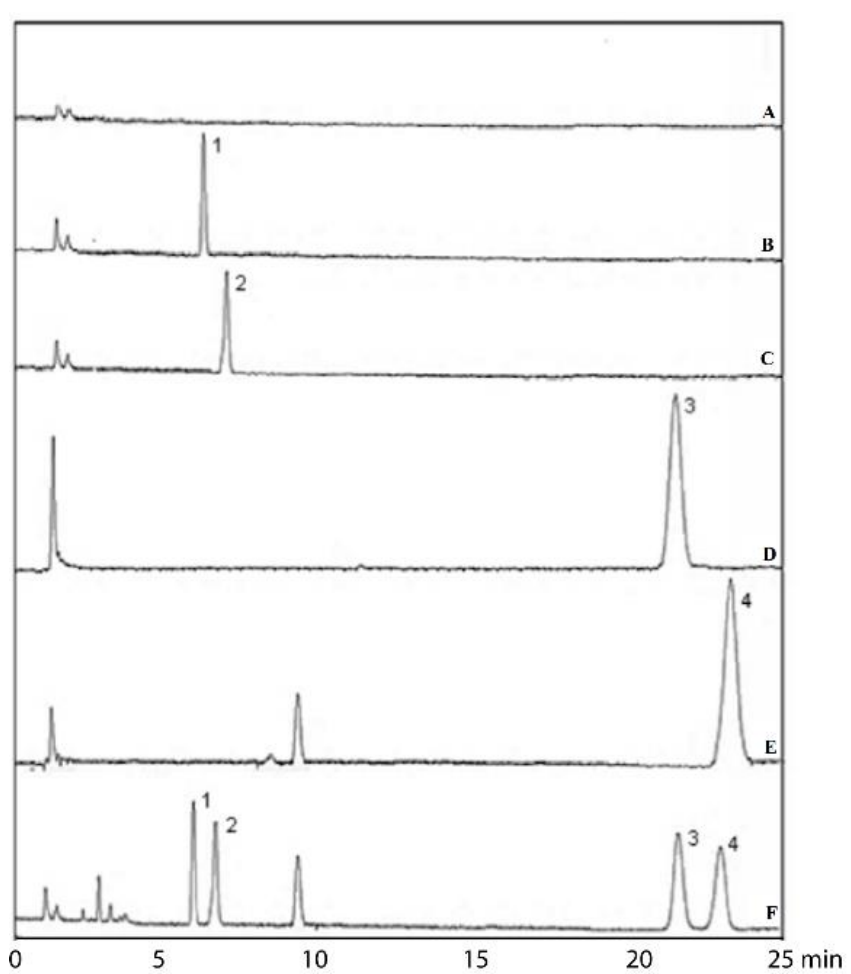

Figura 2. Chromatograms of diluent (A), betulinic acid (B) (peak 1), ursolic acid (C) (peak 2), 3-OBB (D) (peak 3), 3-OBU (E) (peak 4) and a solution containing all compounds (F).

\section{Linearity, $L O D$ and $L O Q$}

All calibration curves were linear in the range of $50-$ $150 \%$ of nominal concentration ( 25.0 to $75 \mu \mathrm{g} / \mathrm{mL}$ ). The mean correlation coefficient (r) values were $>0.996$ for both analytes. Linear regression was applied to confirm the method linearity, and, by residual analysis, it was verified the absence of atypical samples and the homoscedasticity of the residues. LOD was found to be $0.92 \mu \mathrm{g} / \mathrm{mL}$ (UV) and $1.11 \mu \mathrm{g} / \mathrm{mL}$ (CAD) for 3-OBB; $0.92 \mu \mathrm{g} / \mathrm{mL}$ (UV) and $1.16 \mu \mathrm{g} / \mathrm{mL}$ (CAD) for 3-OBU. LOQ was $2.81 \mu \mathrm{g} / \mathrm{mL}$ (UV) and $3.37 \mu \mathrm{g} / \mathrm{mL}$ (CAD) for
3-OBB; $1.29 \mu \mathrm{g} / \mathrm{mL}$ (UV) and $3.50 \mu \mathrm{g} / \mathrm{mL}$ (CAD) for 3OBU.

Linear regression equations and respective correlation coefficients are presented in table 2 .

Table 2. Results of the linearity curves, equations and intercept deviation.

\begin{tabular}{ccccc}
\hline Compound Detection & Linear equation & $\boldsymbol{\sigma}$ Y-axis & $\begin{array}{c}\text { Correlation } \\
\text { Coefficient } \\
\left(\mathbf{r}^{2}\right)\end{array}$ \\
\hline \multirow{2}{*}{$3-\mathrm{OBB}$} & $\mathrm{UV}$ & $6009.8 \mathrm{x}-20467$ & 0.26 & 0.9978 \\
& CAD & $0.2496 \mathrm{x}+0.1786$ & 0.34 & 0.9983 \\
\hline \multirow{2}{*}{$3-\mathrm{OBU}$} & $\mathrm{UV}$ & $3975.3 \mathrm{x}-4654.7$ & 0.12 & 0.9981 \\
& CAD & $0.1355 \mathrm{x}-0.3864$ & 0.32 & 0.9958 \\
\hline
\end{tabular}

a Standard deviation of the Y-axis intercept $(n=3)$.

\section{Precision and accuracy}

Experimental data obtained from the repeatability and intermediate precision are shown in table 3. Values of intra and interday RSD were below $2.0 \%$ for $3-\mathrm{OBB}$ and 3-OBU in both UV and CAD.

Table 3. Results of repeatability and intermediate precision of 3OBB and 3-OBU acids by UV and CAD.

\begin{tabular}{|c|c|c|c|c|}
\hline \multirow[t]{2}{*}{ Compound } & \multicolumn{2}{|c|}{ UV } & \multicolumn{2}{|c|}{ CAD } \\
\hline & Day 1 & Day 2 & Day 1 & Day 2 \\
\hline 3-OBB & & & & \\
\hline Repeatability $(\mu \mathrm{g} / \mathrm{mL})^{\mathrm{a}}$ & 50.0 & 50.5 & 50.0 & 50.5 \\
\hline $\mathrm{RF}(\mu \mathrm{g} / \mathrm{mL} / \mathrm{A})^{\mathrm{b}}$ & 5502.30 & 5563.30 & 0.2553 & 0.2553 \\
\hline $\operatorname{RSD} \%{ }^{\mathrm{c}}$ & 1.02 & 0.70 & 1.25 & 1.43 \\
\hline $\begin{array}{l}\text { Intermediate precision } \\
\left(\mu \mathrm{g} / \mathrm{mL}^{\mathrm{d}}\right)^{-}\end{array}$ & & 50.2 & & 50.2 \\
\hline $\mathrm{RF}(\mu \mathrm{g} / \mathrm{mL} / \mathrm{A})$ & & 5532.80 & & 0.2553 \\
\hline RSD \% & & 1.01 & & 1.28 \\
\hline 3-OBU & & & & \\
\hline Repeatability $(\mu \mathrm{g} / \mathrm{mL})^{\mathrm{a}}$ & 47.8 & 49.9 & 47.8 & 49.9 \\
\hline $\mathrm{RF}(\mu \mathrm{g} / \mathrm{mL} / \mathrm{A})^{\mathrm{b}}$ & 3494.39 & 3491.80 & 0.1291 & 0.1285 \\
\hline $\operatorname{RSD} \%{ }^{c}$ & 1.07 & 1.10 & 1.13 & 1.11 \\
\hline $\begin{array}{l}\text { Intermediate precision } \\
(\mu \mathrm{g} / \mathrm{mL})^{\mathrm{d}}\end{array}$ & & 48.9 & & 48.9 \\
\hline $\mathrm{RF}(\mu \mathrm{g} / \mathrm{mL} / \mathrm{A})$ & & 3493.09 & & 0.1288 \\
\hline RSD \% & & 1.04 & & 1.10 \\
\hline
\end{tabular}

${ }^{a}$ Mean concentration of six replicates, ${ }^{\mathrm{b}}$ response factor; relative standard deviation $(\%) ;{ }^{\mathrm{d}}$ mean concentration of twelve replicates.

As stated previously, in accordance with $\mathrm{ICH}$, since there is no SQR available, accuracy was inferred after the establishment of linearity, selectivity and precision.

\section{Solution Stability}

The stability of $50.0 \mu \mathrm{g} / \mathrm{mL}$ solutions of 3-OBU and 3OBB acids were tested for 24, 48 and $72 \mathrm{~h}$ at room temperature. High stability (RSD $<2.0 \%$ in comparison with fresh solution) was observed under the tested condition in UV and CAD. 


\section{Conclusion}

The analytical method developed for the simultaneous analysis of antimalarials 3-O-butanoylbetulinic and 3-Obutanoylursolic acids by RP-HPLC-UV-CAD demonstrated to be suitable for its purpose. This simple, robust and sensitive technique can be applied with reliability to identify and quantify these drug candidates in further studies.

\section{Acknowledgements}

This study was financed in part by the Coordenação de Aperfeiçoamento de Pessoal de Nível Superior - Brasil (CAPES), Finance Code 001.

\section{Conflict of Interest}

The authors declare no conflicts of interest.

\section{Supplementary Data}

Melting range (FP 90, Mettler Toledo, Switzerland)

Table 4. Melting range results for 3-OBB and 3-OBU compounds.

\begin{tabular}{ccc}
\hline Sample & Melting range & $\begin{array}{c}\text { Melting range } \\
(\mathbf{n}=3)\end{array}$ \\
\hline \multirow{3}{*}{ 3-OBB } & $313.5^{\circ} \mathrm{C}-350.8^{\circ} \mathrm{C}$ & \\
& $312.8^{\circ} \mathrm{C}-348.8^{\circ} \mathrm{C}$ & $312.9{ }^{\circ} \mathrm{C}-351.0{ }^{\circ} \mathrm{C}$ \\
& $312.3{ }^{\circ} \mathrm{C}-353.3{ }^{\circ} \mathrm{C}$ \\
\hline \multirow{3}{*}{$3-\mathrm{OBU}$} & $255.9^{\circ} \mathrm{C}-284.5^{\circ} \mathrm{C}$ & \\
& $257.8^{\circ} \mathrm{C}-281.4^{\circ} \mathrm{C}$ & $256.3{ }^{\circ} \mathrm{C}-283.2{ }^{\circ} \mathrm{C}$ \\
& $255.3{ }^{\circ} \mathrm{C}-283.8{ }^{\circ} \mathrm{C}$ & \\
\hline
\end{tabular}

\section{Differential scanning calorimetry (DSC-60, Shimadzu, Japan)}

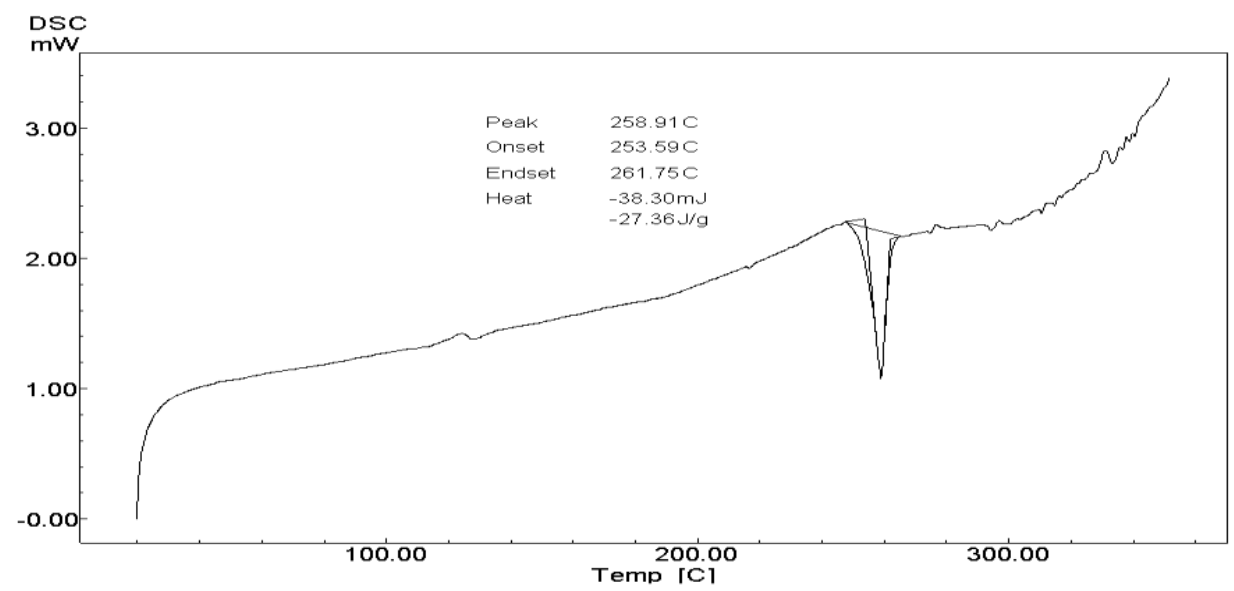

Figure 3. Heating curve of 3-OBU obtained by DSC $\left(10^{\circ} \mathrm{C} / \mathrm{min}\right)$

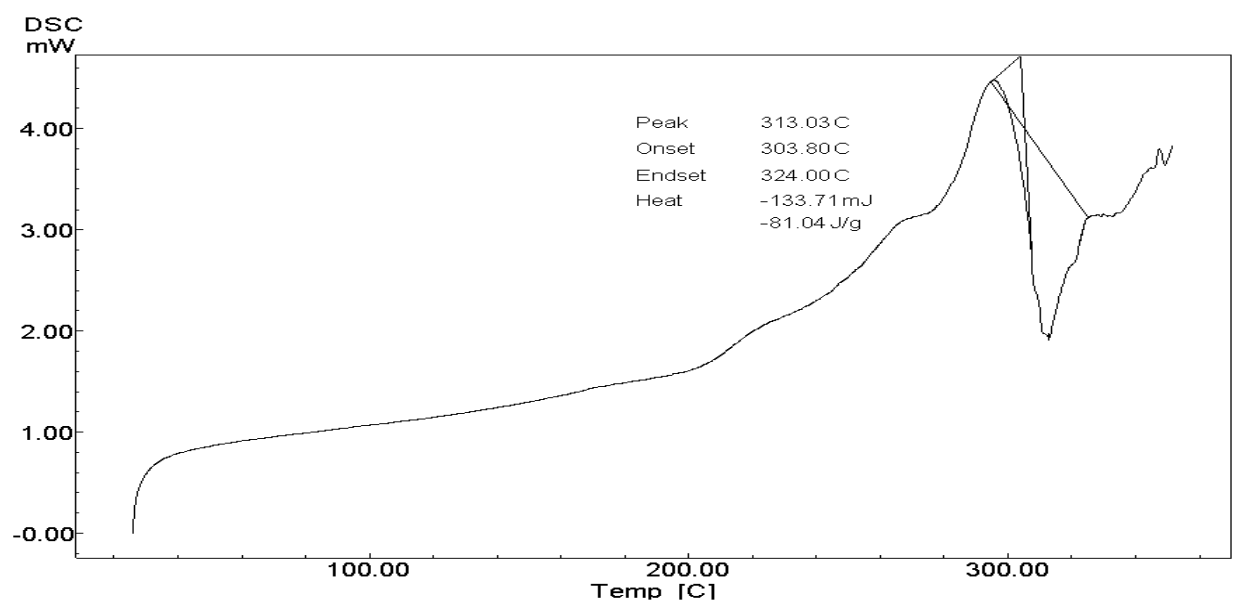

Figure 4. Heating curve of 3 -OBB obtained by DSC $\left(10^{\circ} \mathrm{C} / \mathrm{min}\right)$. 
Nuclear magnetic resonance spectroscopy (NMR 1H and 13C) (DPX, Bruker, Germany)

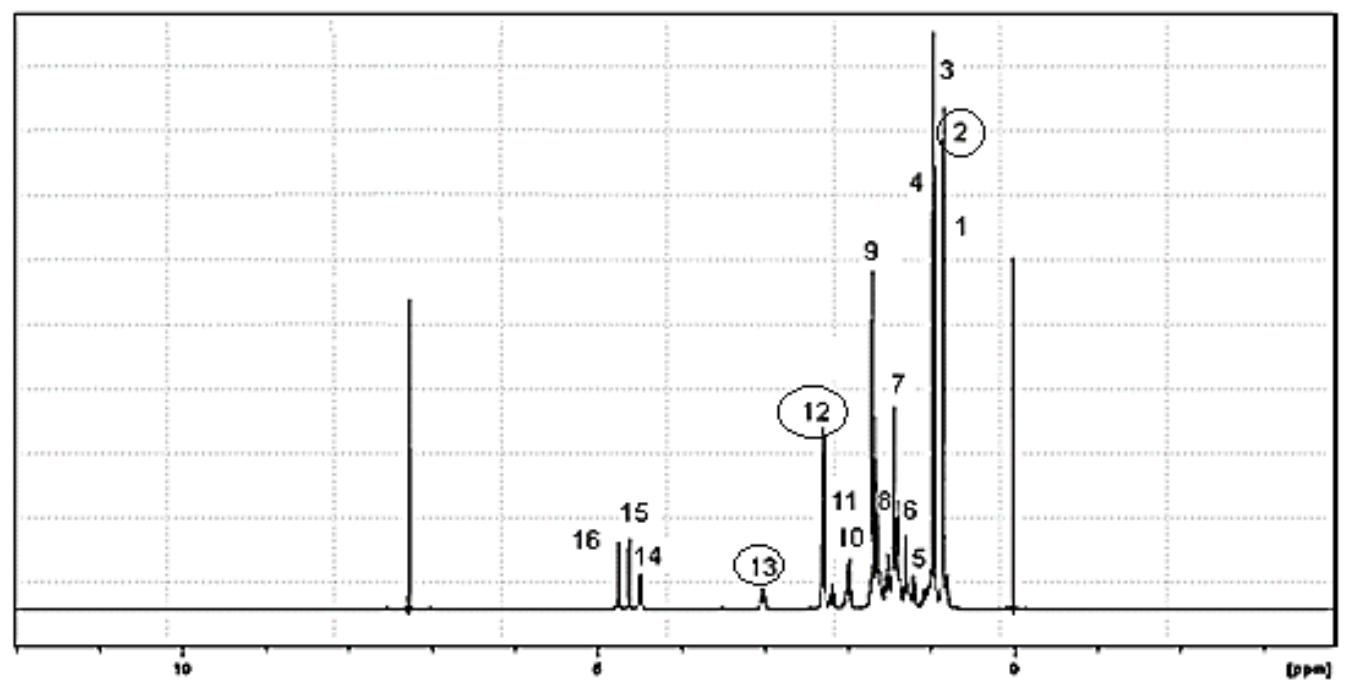

Figure 5. RMN ${ }^{1} \mathrm{H}$ of 3-OBB (400 MHz, $\left.\mathrm{CDCl} 3\right)$. Hydrogens highlighted refer to the ones substituted in $3 \mathrm{C}$.

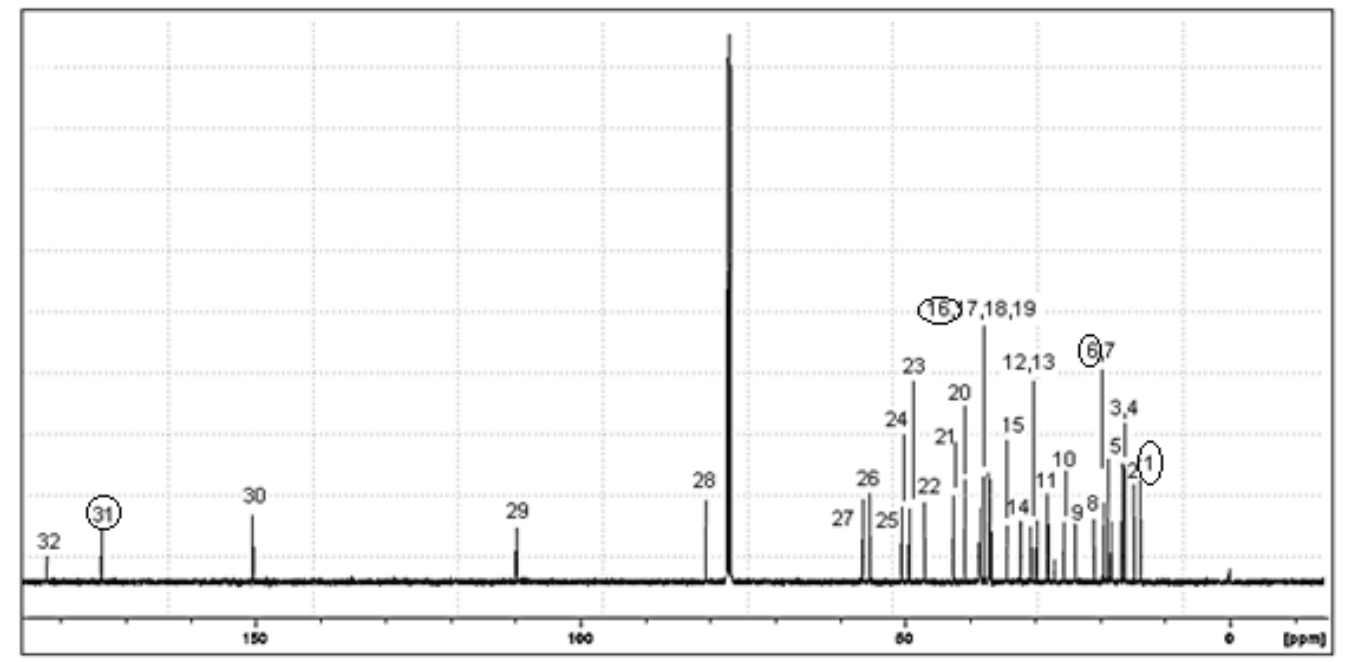

Figure 6. $\mathrm{RMN}{ }^{13} \mathrm{C}$ of 3-OBB (400 MHz, CDCl3). Carbons highlighted refer to the ones substituted in 3C.

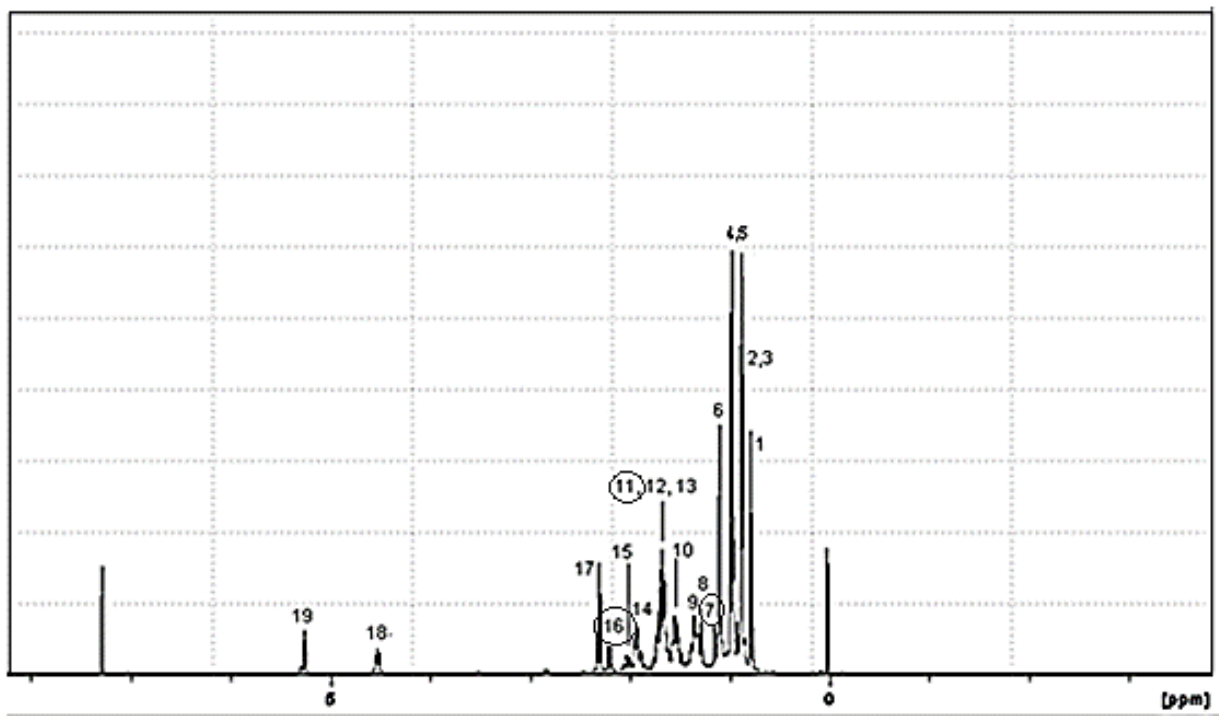

Figure 7. RMN ${ }^{1} \mathrm{H}$ of $3-\mathrm{OBU}(400 \mathrm{MHz}, \mathrm{CDCl} 3)$. Hydrogens highlighted refer to the ones substituted in $3 \mathrm{C}$. 


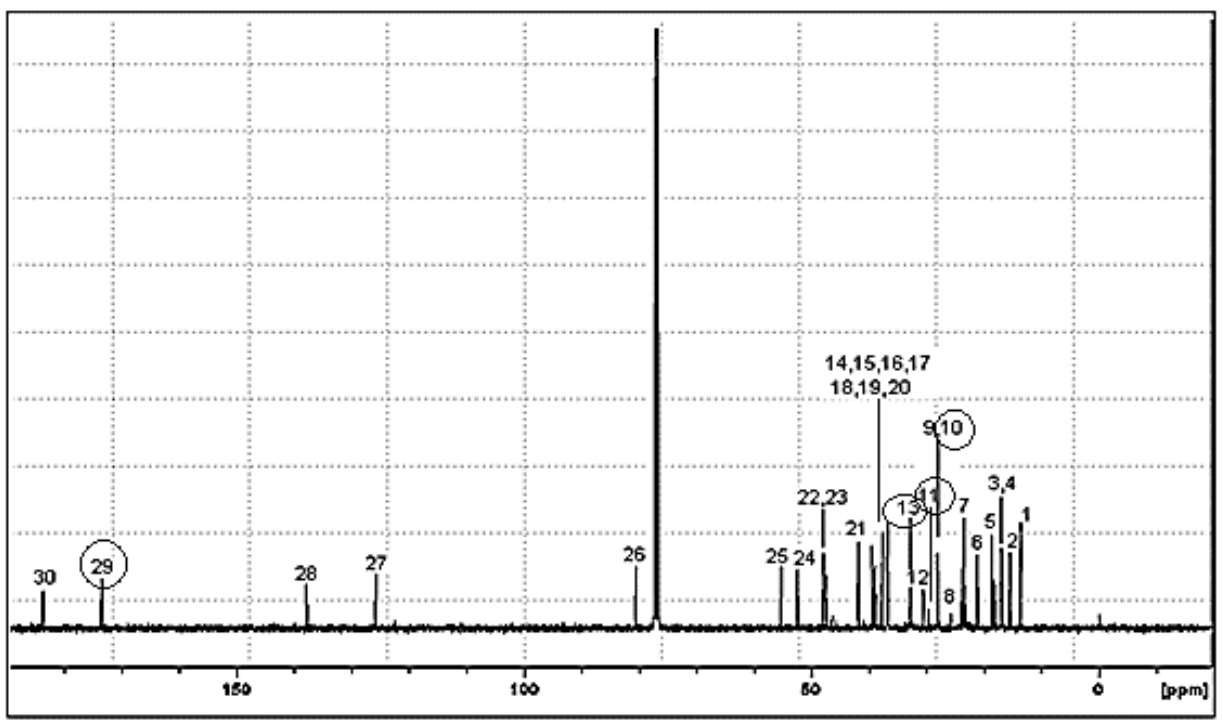

Figure $8 . \mathrm{RMN}^{13} \mathrm{C}$ of 3-OBU (400 MHz, $\mathrm{CDCl}$ ). Carbons highlighted refer to the ones substituted in 3C.

Table 5. RMN $1 \mathrm{H}$ of 3-OBB attributions.

\begin{tabular}{llll}
\hline Position & $\begin{array}{c}\boldsymbol{\delta} \\
(\mathbf{p p m})\end{array}$ & $\begin{array}{c}\text { Multiplicity } \\
- \\
\text { Number of } \\
\text { hydrogens }\end{array}$ & Attribution \\
\hline 1 & 0.90 & $\mathrm{~s}-3 \mathrm{H}$ & $\mathrm{CH} 3$ \\
2 & 0.96 & $\mathrm{~s}-3 \mathrm{H}$ & $\mathrm{CH} 3$ \\
3 & 0.98 & $\mathrm{~s}-6 \mathrm{H}$ & $\mathrm{CH} ; \mathrm{CH} 3$ \\
4 & 1.04 & $\mathrm{~s}-3 \mathrm{H}$ & $\mathrm{CH} 3$ \\
5 & 1.45 & $\mathrm{~m}-2 \mathrm{H}$ & $\mathrm{CH} 2$ \\
6 & 1.50 & $\mathrm{~m}-1 \mathrm{H}$ & $\mathrm{CH}$ \\
7 & 1.62 & $\mathrm{~m}-2 \mathrm{H}$ & $\mathrm{CH} 2$ \\
8 & 1.76 & $\mathrm{t}-1 \mathrm{H}$ & $\mathrm{CH}$ \\
9 & 1.80 & $\mathrm{~s}-3 \mathrm{H}$ & $\mathrm{CH} 3$ \\
10 & 2.04 & $\mathrm{~m}-2 \mathrm{H}$ & $\mathrm{CH} 2$ \\
11 & 2.24 & $\mathrm{t}-2 \mathrm{H}$ & $\mathrm{CH} 2$ \\
12 & 2.31 & $\mathrm{~m}-6 \mathrm{H}$ & $\mathrm{CH} 2 ; \mathrm{CH} 2 ; \mathrm{CH} 2$ \\
13 & 3.14 & $\mathrm{t}-2 \mathrm{H}$ & $\mathrm{CH} 2$ \\
14 & 4.53 & $\mathrm{dd}-1 \mathrm{H}$ & $\mathrm{CH}$ \\
15 & 4.64 & $\mathrm{~s}-1 \mathrm{H}$ & $\mathrm{CH}$ \\
16 & 4.76 & $\mathrm{~s}-1 \mathrm{H}$ & $\mathrm{CH}$ \\
\hline
\end{tabular}

Table 6. RMN ${ }^{13} \mathrm{C} 1 \mathrm{H}$ of 3-OBB attributions.

\begin{tabular}{lll}
\hline Position & $\boldsymbol{\delta}(\mathbf{p p m})$ & Attribution \\
\hline 1 & 13.0 & C 34 \\
2 & 15,0 & C 27 \\
3 & 16.0 & C 26 \\
4 & 16.5 & C 25 \\
5 & 18.1 & C 6 \\
6 & 18.6 & C 33 \\
7 & 19.3 & C 30 \\
8 & 20.8 & C 11 \\
9 & 23.6 & C 2 \\
10 & 25.6 & C 12 \\
11 & 27.9 & C $23 ;$ C 24 \\
12 & 29.7 & C 15 \\
13 & 30.6 & C 21 \\
14 & 32.1 & C 16 \\
15 & 34.2 & C 7 \\
16 & 36.7 & C $22 ;$ C 32 \\
17 & 37 & C 10 \\
18 & 37.1 & C 4 \\
19 & 37.8 & C 13 \\
20 & 38.4 & C 1 \\
21 & 40.7 & C 8 \\
22 & 42.4 & C 14 \\
23 & 46.9 & C 19 \\
24 & 49.3 & C 18 \\
25 & 50.4 & C 9 \\
26 & 55.4 & C 17 \\
27 & 56.4 & C 5 \\
28 & 80.6 & C 3 \\
29 & 109.7 & C 20 \\
30 & 150.3 & C 29 \\
31 & 173.5 & C 31 \\
32 & 183.5 & C 28 \\
\hline & &
\end{tabular}


Table 7. RMN 1H of 3-OBU attributions.

\begin{tabular}{llll}
\hline Position & $\boldsymbol{3}$ (ppm) & $\begin{array}{c}\text { Multiplicity } \\
- \\
\text { Number of } \\
\text { hydrogens }\end{array}$ & Attribution \\
\hline 1 & & $\mathrm{~s}-3 \mathrm{H}$ & $\mathrm{CH} 3$ \\
2 & 0.70 & $\mathrm{~s}-6 \mathrm{H}$ & $\mathrm{CH} 3$ \\
3 & 0.84 & $\mathrm{~s}-3 \mathrm{H}$ & $\mathrm{CH} 3$ \\
4 & 0.87 & $\mathrm{~s}-3 \mathrm{H}$ & $\mathrm{CH} 3$ \\
5 & 0.92 & $\mathrm{~s}-3 \mathrm{H}$ & $\mathrm{CH} 3$ \\
6 & 1.00 & $\mathrm{~d}-3 \mathrm{H}$ & $\mathrm{CH} 3$ \\
7 & 1.05 & $\mathrm{t}-3 \mathrm{H}$ & $\mathrm{CH} 3$ \\
8 & 1.15 & $\mathrm{~s}-3 \mathrm{H}$ & $\mathrm{CH} 3$ \\
9 & 1.19 & $\mathrm{~d}-3 \mathrm{H}$ & $\mathrm{CH} 3$ \\
10 & 1.25 & $\mathrm{~m}-\mathrm{H}$ & $\mathrm{CH}$ \\
11 & 1.52 & $\mathrm{~m}-2 \mathrm{H}$ & $\mathrm{CH} 2$ \\
12 & 1.73 & $\mathrm{~m}-\mathrm{H}$ & $\mathrm{CH} 2$ \\
13 & 1.77 & $\mathrm{dd}-2 \mathrm{H}$ & $\mathrm{CH} 2$ \\
14 & 1.80 & $\mathrm{~d}-\mathrm{H}$ & $\mathrm{CH}$ \\
15 & 1.96 & $\mathrm{t}-2 \mathrm{H}$ & $\mathrm{CH} 2$ \\
16 & 2.08 & $\mathrm{~s}-1 \mathrm{H}$ & $\mathrm{CH}$ \\
17 & 2.23 & $\mathrm{dd}-1 \mathrm{H}$ & $\mathrm{CH}$ \\
18 & 2.39 & $\mathrm{~s}-1 \mathrm{H}$ & $\mathrm{CH}$ \\
\hline
\end{tabular}

Table 8. RMN ${ }^{13} \mathrm{C} 1 \mathrm{H}$ of 3-OBU attributions.

\begin{tabular}{|c|c|c|}
\hline Position & $\delta(\mathrm{ppm})$ & Attribution \\
\hline 1 & 14.0 & C 25 \\
\hline 2 & 15.3 & C 27 \\
\hline 3 & 16.6 & C 26 \\
\hline 4 & 16.9 & C 29 \\
\hline 5 & 18.1 & $\mathrm{C} 6$ \\
\hline 6 & 21.6 & C 30 \\
\hline 7 & 23.1 & C 23 ; C 24 \\
\hline 8 & 25.8 & C 11 \\
\hline 9 & 27.6 & $\mathrm{C} 2$ \\
\hline 10 & 27.7 & C 16 ; C 33 \\
\hline 11 & 29.8 & C 15 \\
\hline 12 & 31.5 & C 21 \\
\hline 13 & 33.0 & C 7 ; C $32 ;$ C 34 \\
\hline 14 & 33.8 & C 22 \\
\hline 15 & 36.9 & C 10 \\
\hline 16 & 37.7 & C 4 \\
\hline 17 & 38.2 & $\mathrm{C} 1$ \\
\hline 18 & 38.8 & C 19 \\
\hline 19 & 39 & C 20 \\
\hline 20 & 39.5 & $\mathrm{C} 8$ \\
\hline 21 & 41.9 & C 14 \\
\hline 22 & 47.3 & C 9 \\
\hline 23 & 47.9 & C 17 \\
\hline 24 & 52.5 & C 18 \\
\hline 25 & 55.3 & C 5 \\
\hline 26 & 80.5 & C 3 \\
\hline 27 & 125.7 & C 12 \\
\hline 28 & 138.4 & C 13 \\
\hline 29 & 173.5 & C 31 \\
\hline 30 & 184.0 & C 28 \\
\hline
\end{tabular}

\section{References}

1.World Health Organization. World Malaria Report 2019. Available at: https://www.who.int/publications/i/item/worldmalaria-report-2019. Accessed August, 2020.
2.World Health Organization. World Malaria Report 2018. Available at: https://www.who.int/malaria/publications/worldmalaria-report-2018/en/. Accessed August, 2020.

3.Mehlotra RK, Mattera G, Bockarie MJ, Maguire JD, Baird JK, Sharma YD, et al. Discordant patterns of genetic variation at two chloroquine resistance loci in worldwide populations of the malaria parasite Plasmodium falciparum; Antimicrob. Agents Chemother. 2008; 52:2212-2222.

4.Woodrow CJ, Krishna S. Antimalarial drugs: recent advances in molecular determinants of resistance and their clinical significance. Cell. Mol. Life. Sci. 2006; 93:1586-1596.

5.Yogeeswari P, Sriram D. Betulinic acid and its derivatives: a review on their biological properties. Curr. Med. Chem. 2005; 12:657-666.

6.Bringmann G, Saeb W, Assi LA, François G, Naraya ASS, Peters K, et al. Betulinic acid: Isolation from Triphyophyllum peltatum and Ancistrocladus heyneanus, antimalarial activity, and crystal structure of the benzyl ester. Planta Med. 1997; 63: 255-257.

7.Silva GNS, Maria NRG, Schuck DC, Cruz LN, Moraes MS, Nakabashi M, et al. Two series of new semissynthetic triterpene derivatives: differences in anti-malarial activity, cytotoxicity and mechanism of action. Malar. J. 2013; 12: 89-96.

8.Fujioka T, Kashiwada Y, Kilkuskie RE, Cosentino LM, Ballas LM, Jiang JB, et al. Anti-AIDS agents, 11 . Betulinic acid and platanic acid as anti-HIV principles from Syzigium claviflorum, and the anti-HIV activity of structurally related triterpenoids; J. Nat. Prod. 1994; 57:243-247.

9.Mayaux JF, Bousseau A, Pauwels R, Huet T, Hénin Y, Dereu N, et al. Triterpene derivatives that block entry of human immunodeficiency virus type 1 into cells; Proc. Natl. Acad. Sci. 1994; 91:3564-3568.

10.Kashiwada Y, Hashimoto F, Cosentino LM, Chen CH, Garrett PE, Lee KH. Betulinic acid and dihydrobetulinic acid derivatives as potent anti-HIV agents; J. Med. Chem. 1996; 39:1016-1017.

11.Mukherjee R, Kumar V, Srivastava SK, Agarwal SK, Burman AC. Betulinic acid derivatives as anticancer agents: structure activity relationship: Anticancer Agents Med. Chem. 2006; 6:271-279.

12.Schühly W, Heilmann J, Çalis I, Sticher O. New triterpenoids with antibacterial activity from Zizyphus joazeiro; Planta Med. 1999; 65:740-743. 
13.Chandramu C, Manohar RD, Krupadanam DGL, Dashavantha RV. Isolation, characterization and biological activity of betulinic acid and ursolic acid from Vitex negundo L. Phytother. Res. 2003; 17:129134.

14.Carmona DBD, Erosa FE, Sosa KG, Pinell GR, Yapu DG, Bacab MJC, et al. Antiprotozoal activity of betulinic acid derivatives. Phytomed. 2010; 17:379382.

15.Liu J. Pharmacology of oleanolic acid and ursolic acid. J. Ethnopharmacol. 1995; 49:57-68.

16.Tokuda H, Origashi $\mathrm{H}$, Koshimizu K, Ito Y. Inhibitory effects of ursolic and oleanolic acid on skin tumor promotion by 12-O-tetradecanoylphorbol-13-acetate. Cancer Lett. 1986; 33:279-285.

17.Ryu SY, Oak MH, Yoon SK, Cho DI, Yoo GS, Kim TS, Kim KM; Anti-allergic and anti-inflammatory triterpenes from the herb of Prunella vulgari. Planta Med. 2000; 66:358-360.

18.Suh N, Honda T, Finlay HJ, Barchowsky A, Williams $\mathrm{C}$, Benoit NE, et al. Novel triterpenoids suppress inducible nitric oxide synthase (iNOS) and inducible cyclooxygenase (COX-2) in mouse machophages; Cancer Res. 1998. 58:717-723.

19.César IC, Nogueira FHA, Pianetti GA; Simultaneous determination of artemether and limefantrine in fixed dose combination tables by HPLC with UV detection. J. Pharm. Biomed. Anal. 2008; 48:951-954.

20.Vehojec T, Obreza A. Review of operating principle and applications of the charged aerosol detector. J. Chromatogr. 2010; 1217:1549-1556.

21.Görög S. Drug safety, drug quality, drug analysis. J. Pharm. Biomed. Anal. 2008; 48:247-253.

22.International Conference on Harmonization (ICH) of Technical Requirements for the Registration of Pharmaceutical for Human Use. Validation of Analytical Procedures: Text and Methodology Q2(R1). Geneva, Switzerland, 2005.

23.Agência Nacional de Vigilância Sanitária (Anvisa). Resolução RDC no 166 de 27 de julho de 2017. Dispõe sobre a validação de métodos analíticos e dá outras providências. Brasília, Brazil: Diário Oficial da União; 2017.

24.United States Pharmacopeia. USP 43-NF 38. Rockville: The United States Pharmacopoeial Convention, 2020.

25.Ma K, Wang H, Zhao M, Xing J. Purity determination and uncertainty evaluation of theophylline by mass balance method, high performance liquid chromatography and differential scanning calorimetry. Anal. Chim. Acta. 2009; 650:227-233. 